\title{
Microwave-assisted synthesis of 5-arylbenzofuran-2-carboxylates via Suzuki coupling using a 2-quinolinealdoxime-Pd(II)-complex
}

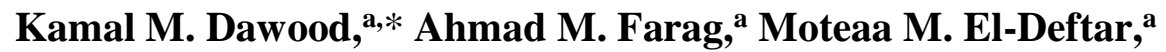 \\ Michael Gardiner, ${ }^{b}$ and Hatem A. Abdelaziz ${ }^{\text {,d }}$ \\ ${ }^{a}$ Department of Chemistry, Faculty of Science, Cairo University, Giza 12613, Egypt \\ ${ }^{b}$ School of Chemistry, University of Tasmania, Hobart TAS 7001, Australia \\ ${ }^{c}$ Department of Pharmaceutical Chemistry, College of Pharmacy, King Saud University, P.O. \\ Box 2457, Riyadh 11451, Saudi Arabia \\ ${ }^{d}$ Department of Applied Organic Chemistry, National Research Center, Dokki, Cairo 12622, \\ Egypt \\ E-mail:dr_dawood@yahoo.com
}

\begin{abstract}
A new quinoline-based $\mathrm{Pd}(\mathrm{II})$-complex was synthesized and its structure was established by single crystal X-ray analysis. Applications of the obtained complex as a precatalyst in SuzukiMiyaura C-C cross-coupling reactions of 4-bromoacetophenone and 5-bromobenzofuran-2carboxylate esters with several aryl- and heteroarylboronic acids were investigated. The catalytic activity of the $\mathrm{Pd}(\mathrm{II})$-precatalyst under microwave irradiating conditions was evaluated.
\end{abstract}

Keywords: Quinolines, benzofurans, palladium catalysis, microwave, Suzuki reactions

\section{Introduction}

Palladium-catalyzed Suzuki-Miyaura cross-coupling reaction of aryl halides with arylboronic acids ${ }^{1-4}$ is one of the most valuable synthetic routes for the preparation of symmetric and asymmetric biaryls, which are important skeletons in the structures of biologically active compounds, ${ }^{5}$ agrochemicals, pharmaceuticals, ${ }^{6-8}$ polymers,${ }^{9}$ ligands, ${ }^{10}$ and functional materials. ${ }^{11}$ The key advantages of the Suzuki-Miyaura cross-coupling are: (i) the mild conditions under which it is conducted, (ii) the high tolerance toward functional groups, (iii) the commercial availability and stability of boronic acids to heat, oxygen and water, and (iv) the ease of handling and separation of boron-containing byproducts from the reaction mixtures. ${ }^{12}$ Over the past few decades, water has been reported to be a powerful solvent because of its safe, environmentally benign and cheap properties. ${ }^{13-17}$ In addition, there is growing research interest on the use of 
microwave irradiation methodology as a heating source, because it assists in achieving rapid incorporation of organic synthesis into broad industrial diversities. ${ }^{18-22}$ Benzofuran-2-carboxylic esters have been reported to possess several biological activities including antifungal ${ }^{23}$ and potent anti-tumor ${ }^{24}$ agents and are inhibitors of human MMP-13 (matrix metalloproteinase-13) ${ }^{25}$ and ischemic cell death. ${ }^{26}$ In continuation of our recent research work concerned on the use of $\mathrm{Pd}(\mathrm{II})$-complexes as precatalysts in $\mathrm{C}-\mathrm{C}$ cross coupling reactions in aqueous media under microwave irradiation conditions, ${ }^{27-36}$ and on the chemistry of 2- and 3-substituted benzofuran derivatives, ${ }^{37-39}$ we report here the synthesis of the new $\mathrm{Pd}(\mathrm{II})$-complex $\mathbf{3}$ to evaluate its catalytic activity in the Suzuki-Miyaura cross-coupling arylation of 5-bromobenzofuran-2-carboxylate esters $\mathbf{7}$ and $\mathbf{1 5 .}$

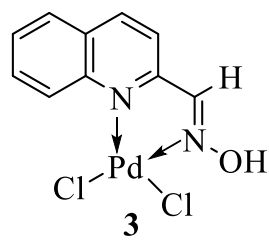

\section{Results and Discussion}

\section{Synthesis and X-ray structure of Pd(II)-complex 3}

2-Quinolinealdoxime (2) was prepared from 2-quinolinealdehyde (1) as described in literature. ${ }^{40}$ Treatment of 2-quinolinealdoxime (2) in methanol with sodium tetrachloropalladate in methanol at room temperature led to the complex 3 (Scheme 1), whose structure was elucidated by elemental and spectral analysis. The structure of the $\mathrm{Pd}(\mathrm{II})$-complex $\mathbf{3}$ was unequivocally determined by carrying out a single crystal X-ray analysis (Figure 1).

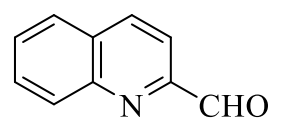

1

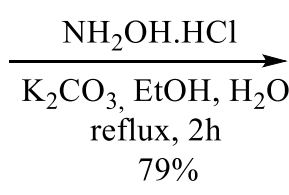

$79 \%$
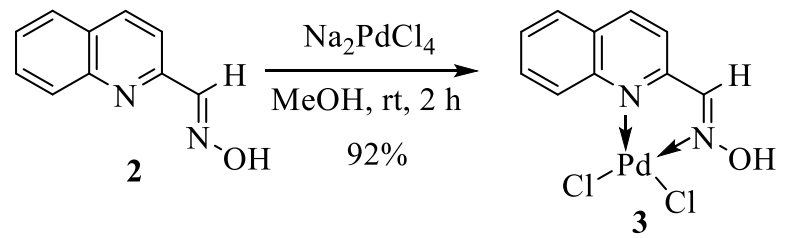

Scheme 1. Preparation of Pd(II)-complex 3.

The crystal structure of complex 3 revealed a bidentate, chelating binding mode for the $N, N^{\prime}-$ ligand. This is the first reported structure of a complex of this ligand. The protonated state of the oxime functionality was established by location of the hydroxyl proton in difference maps and its subsequent positional refinement to a chemically reasonable position implying an intramolecular hydrogen bond with the chloride ligand cis- to the oxime. This feature is consistent with findings for various pyridine-2-aldoxime complexes, such as the mixed oxime/oximato-Pd(II) complex $[\mathrm{Pd}(\mathrm{L}-\mathrm{H}) \mathrm{L}] \mathrm{Cl}^{41}{ }^{41}$ featuring $\mathrm{N}-\mathrm{O}-\mathrm{H} \cdots \mathrm{O}$ hydrogen bonding to the oximato ligand. Intramolecular 
hydrogen bonding is not universally present however, as reported for a cationic square planar $\mathrm{Cu}$ (II) complex of $N, N^{\prime}, N^{\prime \prime}-2,6$-diacetylpyridine dioxime ${ }^{42}$ or examples where tetrahedral metal coordination precludes this feature. ${ }^{43}$

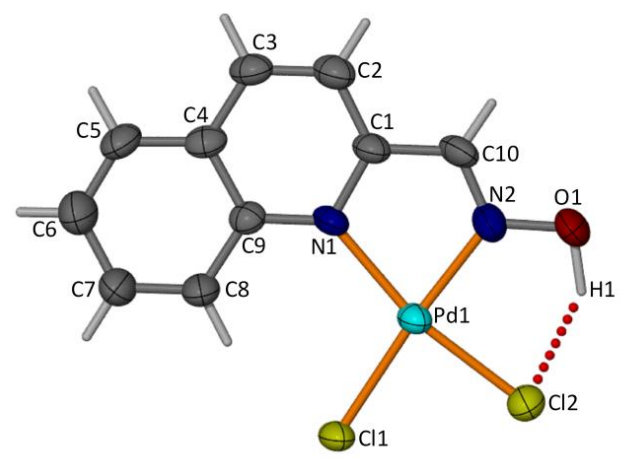

Figure 1. Molecular structure of Pd(II)-complex 3.

\section{Optimization of catalytic conditions for Suzuki cross-coupling}

Firstly, the effect of concentration of $\mathrm{Pd}$ (II)-complex $\mathbf{3}$ on the cross-coupling reaction between 4bromoacetophenone (4) and phenylboronic acid (5a) in water using potassium hydroxide as a base and tetrabutylammonium bromide (TBAB) as an additive under microwave irradiation conditions at $150{ }^{\circ} \mathrm{C}$ for $2 \mathrm{~min}$, was examined as illustrated in Table 1 . Thus, the reaction was firstly carried out using $1 \mathrm{~mol} \%$ of the $\mathrm{Pd}(\mathrm{II})$-complex 3 and the reaction components molar ratios were as follow: 4-bromoacetophenone (4) / phenylboronic acid (5a) / TBAB / KOH: 1 / 1.2 / 0.6 / 2, to give full conversion into 4-acetylbiphenyl (6) in 96\% yield. Secondly, we used $0.7 \mathrm{~mol} \%$ of the precatalyst 3 to give full conversion (97\% yield) after 2 min of microwave irradiation. The coupling reaction was repeated with different concentrations (mol\%) of $\mathrm{Pd}(\mathrm{II})$ complex 3 as shown in Table 1. In all cases, full conversion was obtained even when 0.001 mol\% of the Pd-precatalyst $\mathbf{3}$ was employed in the cross-coupling reaction. It is noteworthy to mention here that, when Pd-complex 3 was used in $0.001 \mathrm{~mol} \%$ the number of mmoles of the reacting species were raised to be: 4-bromoacetophenone (4) (3 mmoles), phenylboronic acid (5a) $(3.6$ mmoles), TBAB (1.8 mmoles), $\mathrm{KOH}(6$ mmoles $)$ and water $(6 \mathrm{~mL})$ to give the 4 acetylbiphenyl (10) in full conversion (92\% yield) after $2 \mathrm{~min}$ of MW irradiation with a turn over number (TON) 92,000 and turnover frequency (TOF) 2,760,000 $\mathrm{h}^{-1}$ (entry 7, Table 1). From the data outlined in Table 1, it can be concluded that the Pd-complex 3 shows excellent catalytic activity, giving rise to extremely high TONs and TOFs.

Some further parameters that may necessary to achieve full conversions and hence maximum yield for the cross-coupling reaction were optimized. Solvents and bases are among such parameters where they play important roles for such purpose. The effect of different bases and solvents on the coupling reaction between 4-bromoacetophenone (4) and phenylboronic acid (5a) were evaluated and the results are outlined in Table 2 . In all cases the Pd-precatalyst $\mathbf{3}$ was used in $0.1 \mathrm{~mol} \%$ and the reaction was carried out under microwave heating for $2 \mathrm{~min}$ in different solvents: water, DMF, toluene and 1,4-dioxane, acetonitrile using several bases; potassium 
hydroxide, potassium carbonate, cesium carbonate and triethylamine. Full conversions with high isolated yields were obtained when water/TBAB in the presence of the inorganic bases $\mathrm{KOH}$, $\mathrm{K}_{2} \mathrm{CO}_{3}$, and $\mathrm{Cs}_{2} \mathrm{CO}_{3}$ were employed as catalytic systems. The use of the organic base: $\mathrm{Et}_{3} \mathrm{~N}$ was not suitable at all regardless the solvent used. Solvents other than water, such as DMF, toluene, 1,4-dioxane and acetonitrile are not proper for this coupling reaction in $\mathrm{KOH}$ or $\mathrm{K}_{2} \mathrm{CO}_{3}$, however the use of cesium carbonate was effective (full conversion with high isolated yields) when toluene or 1,4-dioxane were applied under microwave irradiation. Therefore, water, toluene and 1,4-dioxane are effective solvents for carrying out the coupling reactions especially in the presence of $\mathrm{Cs}_{2} \mathrm{CO}_{3}$. Table 1. Effect of concentration of $\mathrm{Pd}(\mathrm{II})$-complex 3 on Suzuki coupling of 4-bromoacetophenone (4) with phenylboronic acid (5a) under microwave irradiation

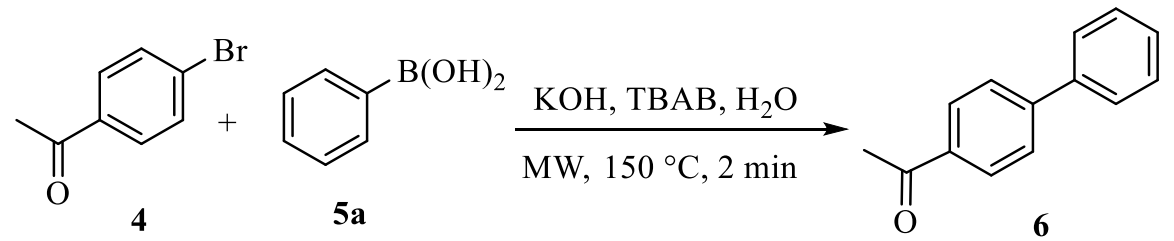

\begin{tabular}{ccccc}
\hline Entry & Cat. 3, mol\% & Yield $\%^{a, b}$ & TON & TOF $\left(\mathrm{h}^{-1}\right)$ \\
\hline 1 & 1 & 96 & 96 & 2880 \\
2 & 0.7 & 97 & 139 & 4170 \\
3 & 0.5 & 95 & 190 & 5700 \\
4 & 0.1 & 94 & 960 & 28800 \\
5 & 0.05 & 96 & 1960 & 58800 \\
6 & 0.01 & 95 & 9500 & 285000 \\
7 & $0.001^{c}$ & 92 & 92000 & 2760000 \\
\hline
\end{tabular}

${ }^{a}$ Reaction Conditions: Bromide/ boronic acid/ KOH/ TBAB /water (3 mL): 1/ 1.2/ 2/ 0.6, under microwave irradiation at $150{ }^{\circ} \mathrm{C}(200 \mathrm{Watt})$. TON: turnover number, TOF: turnover frequency. ${ }^{b}$ The $\%$ values refer to the isolated yields. ${ }^{c}$ Bromide/ boronic acid/ $\mathrm{KOH} / \mathrm{TBAB} /$ water $(6 \mathrm{~mL})$ : $3 / 3.6 / 6 / 1.8$.

Next, optimization of the catalytic activity of complex $\mathbf{3}$ in Suzuki cross-coupling reaction of methyl 5-bromobenzofuran-2-carboxylate (7) with phenylboronic acid (5a) in $\mathrm{Cs}_{2} \mathrm{CO}_{3}$ using different concentrations of $\mathbf{3}$ under microwave condition was investigated as described in Table 3. At first, when water/TBAB/Cs $\mathrm{CO}_{3}$ as catalytic system was applied using $1 \mathrm{~mol} \%$ of the $\mathrm{Pd}(\mathrm{II})$-complex $\mathbf{3}$, the reaction was completed after $10 \mathrm{~min}$ of microwave irradiation. However, the main product, in this case, was found to be 5-bromobenzofuran-2-carboxylic acid due to the hydrolysis of the ester 7 under the aqueous basic hot reaction condition. ${ }^{44}$ Therefore, conduction of the Suzuki coupling of 5a with 7 was performed in toluene/Cs $\mathrm{CO}_{3}$ using $1 \mathrm{~mol} \%$ of the $\mathrm{Pd}(\mathrm{II})$-complex 3 and the reaction components molar ratios were as follow: 5-bromobenzofuran ester 7 / phenylboronic acid (5a) / $\mathrm{Cs}_{2} \mathrm{CO}_{3}: 1 / 1.2 / 2$, in toluene (3 mL) for $15 \mathrm{~min}$ the starting 
substrate 7 was still available as examined by TLC and the product $\mathbf{8}$ was isolated in $67 \%$ yield. Full conversion of 7 into methyl 5-phenylbenzofuran-2-carboxylate (8) was ascertained after 23 min of MW irradiation with $94 \%$ isolated yield (Table 3, run 1). Secondly, the use of 0.7 mol\% of the precatalyst 3 led also to full conversion (97\% yield) after 23 min of microwave irradiation. Furthermore, the coupling reaction was repeated using 0.5 and $0.1 \mathrm{~mol} \%$ of $\mathrm{Pd}(\mathrm{II})$-complex 3 as shown in Table 3 (runs 3 and 4), where the coupling reaction was completed after 23 min of heating giving the coupled product 8 in 95 and $93 \%$ yields, respectively. The maximum TON and TOF values were 930 and 2426, respectively (Table 3, run 4), reflected the moderate activity of the precatalyst 3 towards the Suzuki coupling of 7.

Table 2. Base and solvent effects on the Suzuki coupling of 4-bromoacetophenone (4) with phenylboronic acid (5a) under microwave irradiation

\begin{tabular}{|c|c|c|c|c|c|}
\hline & O & $5 a$ & 0.11 & $\underset{\mathrm{V}, 2 \text { min }}{\stackrel{\mathrm{ol} \% \text { Cat. } 3}{\longrightarrow}}$ & $\prod_{O}$ \\
\hline \multirow{2}{*}{ Entry } & \multirow{2}{*}{ Solvent } & \multicolumn{4}{|c|}{ Yield $\%^{\mathrm{a}, \mathrm{b}}$} \\
\hline & & Base: $\mathrm{KOH}$ & $\mathrm{K}_{2} \mathrm{CO}_{3}$ & $\mathrm{Cs}_{2} \mathrm{CO}_{3}$ & $\mathrm{Et}_{3} \mathrm{~N}$ \\
\hline 1 & Water/TBAB & $100(97)$ & $100(96)$ & $100(89)$ & $54(35)$ \\
\hline 2 & DMF & $80(71)$ & $80(63)$ & $65(50)$ & 30 \\
\hline 3 & Toluene & $87(75)$ & $80(73)$ & $100(92)$ & 30 \\
\hline 4 & 1,4-Dioxane & $90(75)$ & $70(55)$ & $100(95)$ & 25 \\
\hline 5 & Acetonitrile & $60(40)$ & 30 & $40(26)$ & 15 \\
\hline
\end{tabular}

a Reaction conditions: Bromide/ boronic acid/ base/ TBAB/ solvent (3 mL): 1/1.2/2/0.6, microwave irradiation (200 Watt) at $150{ }^{\circ} \mathrm{C}$ for $2 \mathrm{~min} .{ }^{b}$ Conversions were based on ${ }^{1} \mathrm{H}$ NMR spectra of the crude product and the values in parentheses refer to the isolated yields.

Table 3. Catalytic activity of Pd(II)-complex 3 in Suzuki coupling of phenylboronic acid (5a) with methyl 5-bromobenzofuran-2-carboxylate (7) under microwave irradiation

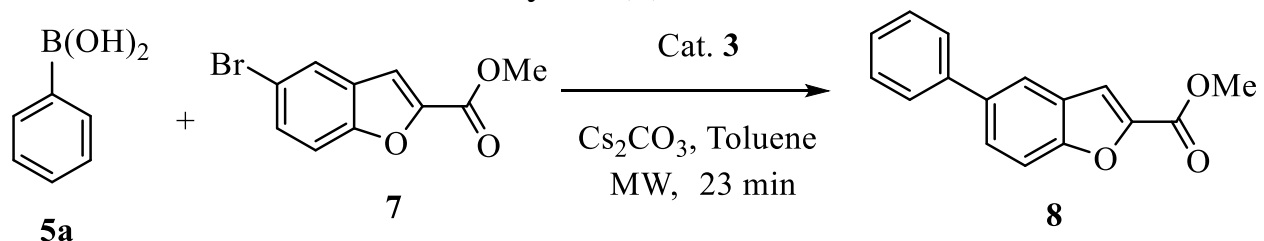

\begin{tabular}{ccccc}
\hline Entry & Cat. 3, mol\% & ${\text { Yield }{ }^{\mathrm{a}}}^{\mathrm{a}}$ & TON & TOF $\left(\mathrm{h}^{-1}\right)$ \\
\hline 1 & 1 & 94 & 94 & 245 \\
2 & 0.7 & 90 & 128 & 334 \\
3 & 0.5 & 95 & 190 & 496 \\
4 & 0.1 & 93 & 930 & 2426 \\
\hline
\end{tabular}


${ }^{a}$ Reaction conditions: Bromide 7: $1 \mathrm{mmol}$; phenylboronic acid (5a): $1.2 \mathrm{mmol}$; $\mathrm{Cs}_{2} \mathrm{CO}_{3}: 2 \mathrm{mmol}$; toluene: $3 \mathrm{~mL}$, Pd-complex 3, microwave heating (200 Watt) at $150{ }^{\circ} \mathrm{C}$.

\section{Suzuki cross-coupling of methyl 5-bromobenzofuran-2-carboxylate (7)}

Next, the application of the $\mathrm{Pd}(\mathrm{II})$-complex 3 was extended to Suzuki cross-coupling reactions between methyl 5-bromobenzofuran-2-carboxylate (7) and further arylboronic acids $\mathbf{5 b - g}$ (Table 4). Thus, employing $0.1 \mathrm{~mol} \%$ of the complex 3 in the coupling of the bromide 7 with 4 chlorophenylboronic acid $\mathbf{5 b}$ in toluene/ $\mathrm{Cs}_{2} \mathrm{CO}_{3}$ resulted in full conversion of $\mathbf{7}$, after 25 min of microwave irradiation, into methyl 5-(4-chlorophenyl)benzofuran-2-carboxylate (9) in 96\% isolated yield (Table 4, run 2).

Similarly, the arylboronic acids 5c-g coupled smoothly with the 5-bromobenzofuran ester (7) under the same experimental conditions to give the corresponding cross-coupled products methyl 5-arylbenzofuran-2-carboxylates 10-14 in high isolated yields as postulated in Table 4. It is notable to mention that, coupling of the arylboronic acids 5e-g with 7 (Table 4, runs 5-7) took longer reaction times and the isolated yields were lower than the other derivatives. The structures of the coupling products were confirmed by their ${ }^{1} \mathrm{H}$ and ${ }^{13} \mathrm{C}$ NMR, MS spectra and elemental analyses. The ${ }^{1} \mathrm{H}$ NMR spectrum of methyl 5-(4-methylphenyl)benzofuran-2-carboxylate (10), as an example of the series prepared, revealed characteristic singlet signals at $\delta 2.42$ and 4.0 due to 4-methylphenyl and the Me-ester protons, respectively. The ${ }^{13} \mathrm{C}$ NMR spectrum of 10 showed two aliphatic carbons at $\delta 21$ and 52.3. The mass spectrum of compound 10 showed a peak $\left(\mathrm{M}^{+}\right)$ at $m / z, 266$ due to its molecular ion.

Table 4. Suzuki cross-coupling of methyl 5-bromobenzofuran-2-carboxylate (7) with arylboronic acids $\mathbf{5 a - g}$

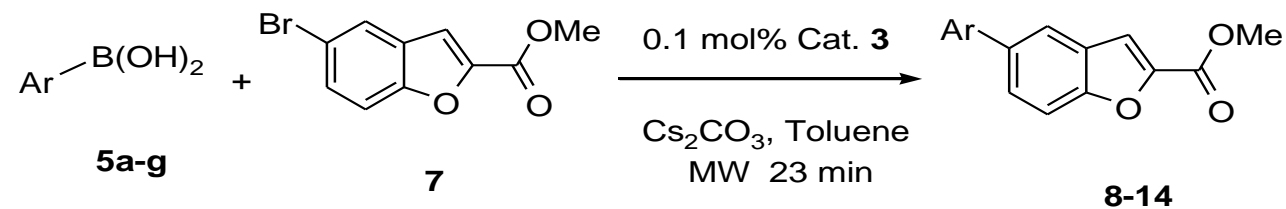

Entry
$\mathrm{B}(\mathrm{OH})_{2}$




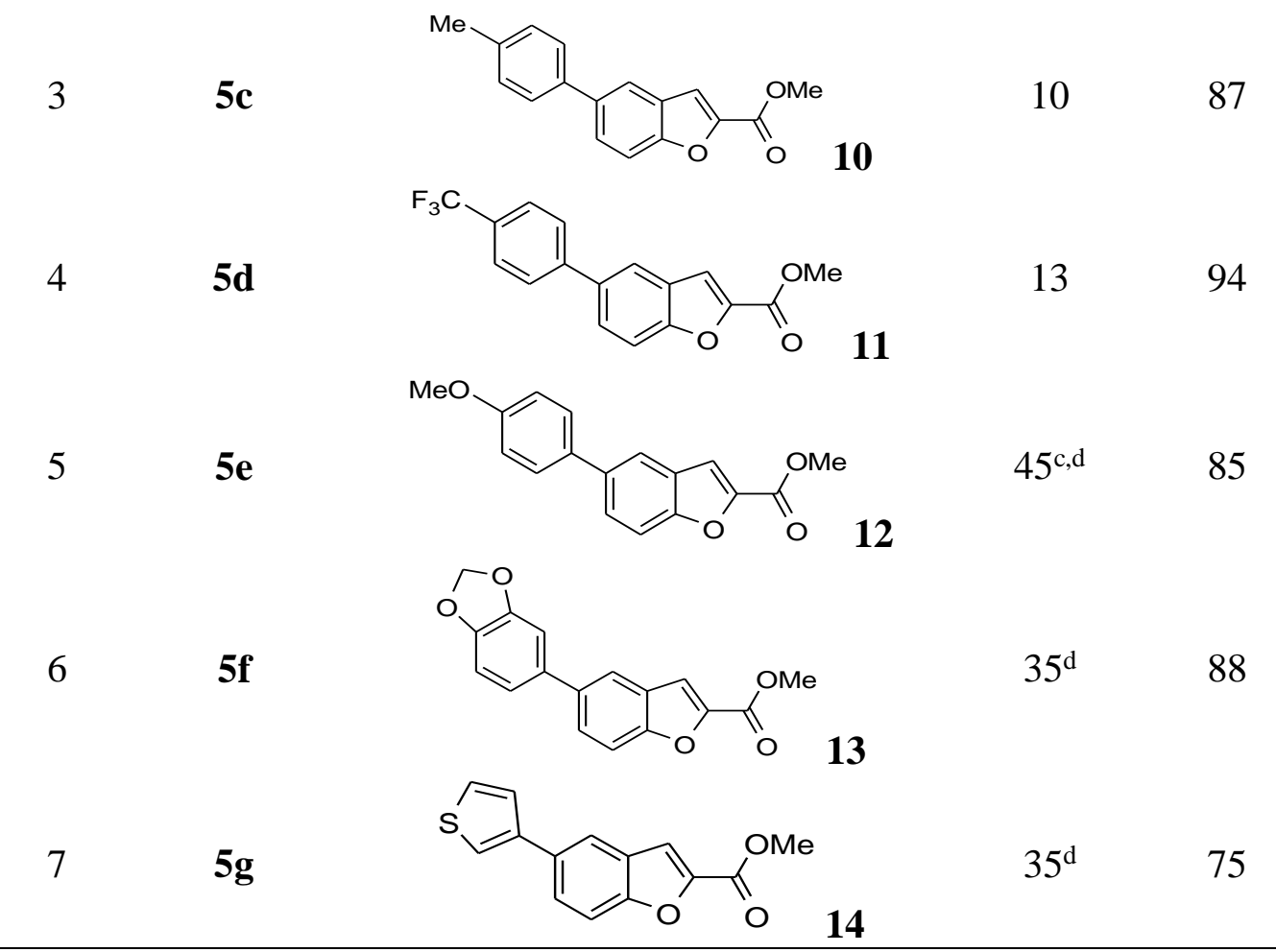

aReaction conditions: Bromide 7 (1 mmol); arylboronic acids 5a-g $(1.2 \mathrm{mmol}) ; \mathrm{Cs}_{2} \mathrm{CO}_{3}(2$ mmol); toluene: $3 \mathrm{~mL}$, Pd-complex 3: $0.1 \mathrm{~mol} \%$, microwave heating (200 Watt) at $150{ }^{\circ} \mathrm{C}$. ${ }^{b}$ The $\%$ values refer to isolated yields. 'When the irradiation was stopped after $30 \mathrm{~min}$, the starting material $\mathbf{7}$ was still present and the product $\mathbf{1 2}$ was isolated in 53\% yield. ${ }^{\mathrm{d}} \mathrm{In}$ all cases, traces of the starting material 7 were detected by TLC and the yield did not change when the reaction was repeated using 0.5 mol\% of the Pd-complex 3 .

\section{Suzuki cross-coupling of ethyl 5-bromobenzofuran-2-carboxylate (15)}

The catalytic activity of the Pd(II)-precatalyst 3 in the Suzuki cross-coupling of ethyl 5bromobenzofuran-2-carboxylate (15) with arylboronic acids 5a,b under typical reaction condition above was also evaluated. Therefore, carrying out the coupling reaction of $\mathbf{1 5}$ with 5a,b in $\mathrm{Cs}_{2} \mathrm{CO}_{3}$ as base and toluene as solvent using 0.1 mol\% of the complex 3 under microwave condition for $23 \mathrm{~min}$ led to full conversion into the corresponding ethyl 5arylbenzofuran-2-carboxylates $\mathbf{1 6}$ and $\mathbf{1 7}$ in 93 and 96\% isolated yields, respectively (Scheme 2).

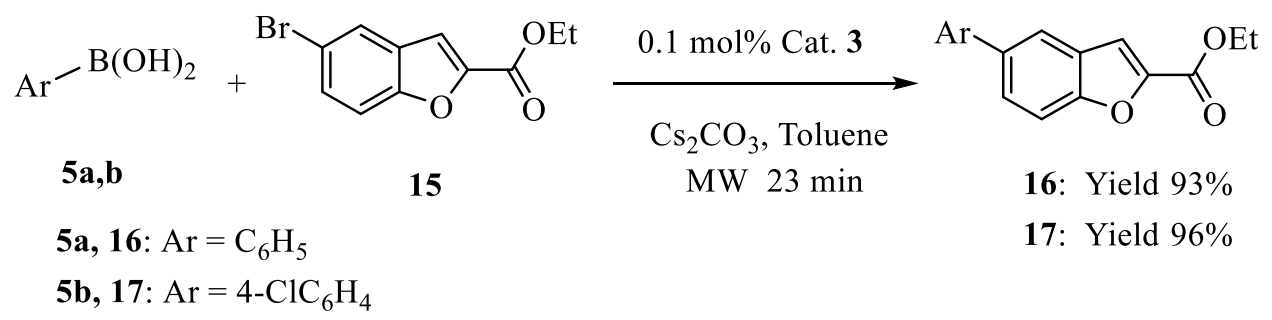

Scheme 2. Suzuki cross-coupling of ethyl 5-bromobenzofuran-2-carboxylate (15). 


\section{Conclusions}

The 2-quinolinealdoxime-Pd(II)-complex 3 was found to be extremely active precatalyst for Suzuki cross-coupling reaction of 4-bromoacetophenone with phenylboronic acid, under ecofriendly green condition (water and microwave irradiation), with very high TON and TOF values. Complex 3 was also found as an effective precatalyst for the coupling of 5bromobenzofuran-2-carboxylate esters $\mathbf{7}$ and $\mathbf{1 5}$ for the synthesis of new 5-arylbenzofran-2carboxylates. These high catalytic findings of $\mathbf{3}$ are important for forthcoming industrial applications.

\section{Experimental Section}

General. Melting points were determined in open glass capillaries with a Gallenkamp apparatus. The infrared spectra were recorded in potassium bromide disks on a Pye Unicam SP 3-300 and Shimadzu FTIR 8101 PC infrared spectrophotometer. NMR spectra were recorded with a Varian Mercury VXR-300 NMR spectrometer at $300 \mathrm{MHz}\left({ }^{1} \mathrm{H} \mathrm{NMR}\right)$ and at $75 \mathrm{MHz}\left({ }^{13} \mathrm{C}\right.$ NMR) using $\mathrm{CDCl}_{3}$ as solvent and internal standard $\left(\delta 7.27\right.$ and $77.36 \mathrm{ppm}$, for ${ }^{1} \mathrm{H}$ NMR and ${ }^{13} \mathrm{C}$ NMR, respectively). Mass spectra (EI) were obtained at $70 \mathrm{eV}$ with a type Shimadzu GCMQP $1000 \mathrm{EX}$ spectrometer. Analytical thin-layer chromatography (TLC) was performed using pre-coated silica gel 60778 plates (Fluka), and the spots were visualized with UV light at $254 \mathrm{~nm}$. Fluka silica gel 60741 (70-230 mesh) was used for flash column chromatography. Elemental analyses were carried out by the Microanalytical Center of Cairo University, Giza, Egypt. Microwave experiments were carried out using a CEM Discover Labmate ${ }^{\mathrm{TM}}$ microwave apparatus (300 W with ChemDriver ${ }^{\mathrm{TM}}$ Software). Data for the structure of complex 3 was obtained on the MX2 beamline at the Australian Synchrotron, Victoria, Australia. 5-Bromobenzofuran-2-carboxylate esters $\mathbf{7},{ }^{45}$ and $\mathbf{1 5},{ }^{46}$ were prepared following literature procedures. 4-Bromoacetophenone (4) and arylboronic acids 5a-g were used as purchased without further purification.

Synthesis of 2-quinolinealdoxime-Pd(II)-complex 3. A solution of sodium tetrachloropalladate (294 $\mathrm{mg}, 1 \mathrm{mmol})$ in methanol $(2 \mathrm{~mL})$ was added portionwise to a stirred solution of 2 quinolinealdoxime (2) $(172 \mathrm{mg}, 1 \mathrm{mmol})$ in methanol $(2 \mathrm{~mL})$. After stirring for $2 \mathrm{~h}$ a yellow precipitate was formed that was then filtered off, washed with methanol followed by water and again with ethanol and finally dried. The Pd(II)-complex 3 was isolated in a pure state $(321 \mathrm{mg}$, $92 \%)$ as yellow powder and was used without further purifications. $\mathrm{Mp}>300{ }^{\circ} \mathrm{C}$; IR $\left(v_{\max }, \mathrm{cm}^{-}\right.$ $\left.{ }^{1}\right): 3100,3034,1460,1348,1012,880 .{ }^{1} \mathrm{H}$ NMR (DMSO-d 6 ) $\delta_{\mathrm{H}} 7.29-7.73\left(3 \mathrm{H}_{\text {arom }}, \mathrm{m}, 3 \mathrm{CH}\right), 7.78$ $-8.07\left(3 \mathrm{H}_{\text {arom }}, \mathrm{m}, 3 \mathrm{CH}\right), 9.66(1 \mathrm{H}, \mathrm{s}, \mathrm{CH}=\mathrm{N}), 11.94(1 \mathrm{H}, \mathrm{s}, \mathrm{OH}) ;{ }^{13} \mathrm{C}$ NMR $\left(\mathrm{DMSO}_{-} \mathrm{d}_{6}\right) \delta_{\mathrm{c}} 120.4$, 127.5, 128.1, 128.4, 128.6, 131.3, 140.3, 142.0, 145.6, 156.5. Anal. Calcd for $\mathrm{C}_{10} \mathrm{H}_{8} \mathrm{Cl}_{2} \mathrm{~N}_{2} \mathrm{OPd}$ (349.51): C, 34.36; H, 2.31; N, 8.02\%. Found: C, 34.57; H, 2.42; N, 8.29\%. 
X-Ray structure determination of Pd(II)-complex 3. Crystals of complex 3 were obtained from a saturated, hot solution of acetonitrile that was allowed to cool slowly to room temperature. Data were collected at $-173{ }^{\circ} \mathrm{C}$ on a cut, thin pale yellow needle-like crystal mounted on a Hampton Scientific cryoloop at the MX2 beamline of the Australian Synchrotron. ${ }^{47}$ Data completeness is limited by the single axis goniometer on the MX beamlines at the Australian Synchrotron, which also prevented absorption correction. The structures were solved by direct methods with SHELXS-97, refined using full-matrix least-squares routines against $\mathrm{F}^{2}$ with SHELXL-97, ${ }^{48}$ and visualized using X-SEED. ${ }^{49}$ All non-hydrogen atoms were refined anisotropically. Disordered lattice solvent was apparent, which could not be modeled, requiring the use of SQUEEZE to remove its contribution. Details are provided in the cif file and summarized in the figure caption. The $\mathrm{OH}$ proton was located and positionally refined, while all other hydrogen atoms were placed in calculated positions and refined using a riding model with

fixed $\mathrm{C}-\mathrm{H}$ distances of $0.95 \AA\left(s p^{2} \mathrm{CH}\right)$. The thermal parameters of all hydrogen atoms were estimated as $U_{\text {iso }}(\mathrm{H})=1.2 U_{\text {eq }}(\mathrm{C})$. Crystal data for complex 3: $\mathrm{C}_{10} \mathrm{H}_{8} \mathrm{Cl}_{2} \mathrm{~N}_{2} \mathrm{OPd}, M=349.48$, trigonal, $a=28.922(5), c=8.1550(15) \AA, U=5907.6(17) \AA^{3}, T=100 \mathrm{~K}$, space group $R-3$ (no. 148), $Z=18,22437$ reflections measured, 2392 unique $\left(R_{\text {int }}=0.1475\right), 2124>4 \sigma(F), R=0.0638$ (observed), $R_{w}=0.1190$ (all data). Thermal ellipsoids are shown at the $50 \%$ probability level. Diffuse lattice solvent $(\mathrm{NCMe})$ is omitted for clarity. Selected bond lengths $(\AA)$ and angles $\left(^{\circ}\right)$ : Pd1-N1,N2,Cl1,Cl2 2.114(6), 1.988(6), 2.3035(17), 2.2860(19), C1-C10 1.433(11), C10-N2 1.268(10), N2-O1 1.372(8), O1-H1 1.05(14), H1Cl2 2.03(14), N1-Pd1-N2 79.0(2), Cl1-Pd1Cl2 86.65(7), N-Pd1-Cl $l_{\text {cis,trans }} 88.90(19)-105.51(15), 167.72(15)-175.54(19)$, N2-O1-H1 101(8), O1-H1 $\cdots \mathrm{Cl} 2$ 145(11). CCDC-893760 contains the supplementary crystallographic data for this paper. These data can be obtained free of charge from the Cambridge Crystallographic Data Centre via www.ccdc.cam.ac.uk/data_request/cif

\section{Effect of concentration of Pd(II)-complex 3 on Suzuki coupling of 4-bromoacetophenone} (8) with phenylboronic acid (5a) in water under microwave irradiation. A mixture of 4bromoacetophenone (4) (199 mg, $1 \mathrm{mmol}$ ) and phenylboronic acid 5a (146 mg, $1.2 \mathrm{mmol}$ ), TBAB (194 mg, $0.6 \mathrm{mmol})$, Pd complex 5 (4.59 mg, $1 \mathrm{~mol} \%)$ KOH (112 mg, $2 \mathrm{mmol})$ and water $(3 \mathrm{~mL})$ were mixed in a process glass vial. The vial was capped properly, and thereafter the mixture was heated under microwave conditions at $150{ }^{\circ} \mathrm{C}$ and 200 Watt for 2 min to give 4acetyl-1,1'-biphenyl (6). The same experiment was repeated using different concentrations of the palladium complex $\mathbf{3}$. The amount (mol\%) of the Pd-complex 3 was changed with respect to 4bromoacetophenone $(0.7,0.5,0.1,0.05$ and 0.01 mol\% of complex 3 with 1 mmol scale of 4bromoacetophenone. The same experiment was then repeated using 0.001 mol\% of complex 3 and $3 \mathrm{mmol}$ scale of 4-bromoacetophenone. The molar ratio of the reaction components were in all cases as follows; 4-bromoacetophenone, phenylboronic acid, TBAB, KOH, water: 1 / 1.2 / 0.6 / 2 / $3 \mathrm{~mL}$ water. The yield \% versus concentration of Pd-complex $\mathbf{3}$ is shown in Table 1. 
Effect of base and solvent on Suzuki coupling of 4-bromoacetophenone with phenylboronic acid under microwave heating. A mixture of 4-bromoacetophenone (4) (199 mg, $1 \mathrm{mmol}$ ) and phenylboronic acid 5a (146 mg, $1.2 \mathrm{mmol}$ ), TBAB (194 mg, $0.6 \mathrm{mmol}$ ), palladium(II)precatalyst $3(0.4 \mathrm{mg}, 0.1 \mathrm{~mol} \%)$, KOH (112 mg, $2 \mathrm{mmol})$ and water $(3 \mathrm{~mL})$ was heated under microwave conditions at $150{ }^{\circ} \mathrm{C}$ and 200 Watt for 2 minutes to give 4-acetyl-1,1'-biphenyl (6). The same experiment was repeated using different solvents (DMF, toluene and 1,4-dioxane, acetonitrile) and bases $\left(\mathrm{KOH}, \mathrm{K}_{2} \mathrm{CO}_{3}\right.$, and $\left.\mathrm{Cs}_{2} \mathrm{CO}_{3}\right)$. The molar ratio of the reaction components were in all cases as follows; 4-bromoacetophenone, phenylboronic acid, TBAB (in case of water), base, solvent: 1 / 1.2 / 0.6 / 2 / 3 mL. The yield \% versus different solvents and bases are outlined in Table 2 . The cross-coupled product, in each time, was then extracted with EtOAc $(3 \mathrm{x}$ $20 \mathrm{~mL}$ ). The combined organic extracts were dried over anhydrous $\mathrm{MgSO}_{4}$ then filtered and the solvent was evaporated under reduced pressure. The residue was then subjected to separation via flash column chromatography with petroleum $n$-hexane/EtOAc $(9: 1)$ as an eluent to give 4acetyl-1,1'-biphenyl (6) as colourless solid. Mp 118-120 ${ }^{\circ} \mathrm{C}$ (Lit. ${ }^{50} \mathrm{mp} 119-120{ }^{\circ} \mathrm{C}$ ); ${ }^{1} \mathrm{H}$ NMR $\left(\mathrm{CDCl}_{3}\right) \delta_{\mathrm{H}} 2.65\left(3 \mathrm{H}, \mathrm{s}, \mathrm{CH}_{3}\right), 7.41-7.51\left(3 \mathrm{H}_{\text {arom }}, \mathrm{m}, 3 \mathrm{CH}\right), 7.62-7.66\left(2 \mathrm{H}_{\text {arom }}, \mathrm{m}, 2 \mathrm{CH}\right), 7.70$ $\left(2 \mathrm{H}_{\text {arom }}, \mathrm{d},{ }^{3} J_{\mathrm{HH}} 8.1 \mathrm{~Hz}, 2 \mathrm{CH}\right), 8.04\left(2 \mathrm{H}, \mathrm{d},{ }^{3} J_{\mathrm{HH}} 8.1 \mathrm{~Hz}, 2 \mathrm{CH}\right)$.

Effect of concentration of Pd(II)-complex 3 on Suzuki coupling of methyl 5bromobenzofuran-2-carboxylate (7) with phenylboronic acid (5a) in toluene under microwave irradiation. A mixture of methyl 5-bromobenzofuran-2-carboxylate (7) (255 mg, 1 mmol), phenylboronic acid (5a) (146 mg, $1.2 \mathrm{mmol}), \mathrm{Cs}_{2} \mathrm{CO}_{3}(651 \mathrm{mg}, 2 \mathrm{mmol})$ and palladium(II)-precatalyst $3(1 \mathrm{~mol} \%)$ in toluene $(3 \mathrm{~mL})$ were mixed in a process vial. The vial was capped properly, and thereafter the mixture was heated under microwave irradiating conditions at $150{ }^{\circ} \mathrm{C}$ and 200 Watt. The reaction was complete after 23 minutes (monitored by TLC). The same experiment was repeated using different concentrations of the palladium complex 3. The amount $(\mathrm{mol} \%)$ of the Pd-complex 3 was changed with respect to 5bromobenzofuran ester $7(0.7,0.5$ and $0.1 \mathrm{~mol} \%)$ of complex 3 using 1 mmol scale of 7 . The molar ratio of the reaction components were in all cases as follows; 5-bromobenzofuran ester $\mathbf{7}$, phenylboronic acid (5a), $\mathrm{Cs}_{2} \mathrm{CO}_{3}$, toluene (mL): 1 / 1.2 / 2 / 3. The yield \% versus concentration of Pd-complex 3 is shown in Table 3. In each case, the reaction mixture was extracted with EtOAc $(3 \times 20 \mathrm{~mL})$. The combined organic extracts were dried over anhydrous $\mathrm{MgSO}_{4}$ then filtered off and the solvent was evaporated under reduced pressure. The product was purified with flash column chromatography using $n$-hexane/EtOAc $(7: 1)$ as an eluent to give methyl 5phenylbenzofuran-2-carboxylate $(\mathbf{8})$.

Suzuki coupling of methyl 5-bromobenzofuran-2-carboxylate (7) with arylboronic acids 5a$\mathrm{g}$ in toluene under microwave. A mixture of the methyl 5-bromobenzofuran-2-carboxylate 7 (255 mg, $1 \mathrm{mmol})$, and the appropriate arylboronic acids 5a-g (1.2 mmol), Pd(II)-complex 3 (0.4 $\mathrm{mg}, 0.1 \mathrm{~mol} \%), \mathrm{Cs}_{2} \mathrm{CO}_{3}(651 \mathrm{mg}, 2 \mathrm{mmol})$ in toluene $(3 \mathrm{~mL})$ were mixed in a process vial. The vial was capped properly, and thereafter the mixture was heated under microwave irradiating 
conditions at $150{ }^{\circ} \mathrm{C}$ (200 Watt) for the appropriate reaction times as depicted in Table 4. After the reaction was almost complete (monitored by TLC), the reaction mixture was extracted with EtOAc $(3 \times 20 \mathrm{~mL})$. The combined organic extracts were dried over anhydrous $\mathrm{MgSO}_{4}$ then filtered off and the solvent was evaporated under reduced pressure. The products were purified with flash column chromatography using $n$-hexane/EtOAc (7:1) as an eluent to give the corresponding pure 5-arylbenzofuran-2-carboxylates 8-14.

Methyl 5-phenylbenzofuran-2-carboxylate (8). White powder, mp. $132-134{ }^{\circ} \mathrm{C}$; IR $\left(v_{\max }, \mathrm{cm}^{-}\right.$ $\left.{ }^{1}\right): 3064,2957,2918,1724,1564,1455,1436,1215,1161 ;{ }^{1} \mathrm{H}$ NMR $\left(\mathrm{CDCl}_{3}\right): \delta_{\mathrm{H}} 4.0(3 \mathrm{H}, \mathrm{s}$, $\left.\mathrm{CO}_{2} \mathrm{CH}_{3}\right), 7.37-7.49\left(3 \mathrm{H}_{\text {arom }}, \mathrm{m}, 3 \mathrm{CH}\right), 7.57-7.68\left(5 \mathrm{H}_{\text {arom }}, \mathrm{m}, 5 \mathrm{CH}\right), 7.87\left(1 \mathrm{H}_{\text {arom }}, \mathrm{s}, 1 \mathrm{CH}\right) ;{ }^{13} \mathrm{C}$ NMR $\left(\mathrm{CDCl}_{3}\right): \delta_{\mathrm{C}} 52.4,112.4,114.1,121.1,125.7,127.2,127.4,127.5,128.8,137.6,140.8$, 145.9, 155.2, 159.8; MS (EI, $70 \mathrm{eV}): \mathrm{m} / z(\%) 252(42.9)\left[\mathrm{M}^{+}\right], 184(23.8), 165$ (61.9), 128 (33.3), 110 (61.9), 83 (100), 70 (66.7). Anal. Calcd for $\mathrm{C}_{16} \mathrm{H}_{12} \mathrm{O}_{3}$ (252.26): C, 76.18; H, 4.79\%. Found: C, 76.23; H, 4.86\%.

Methyl 5-(4-chlorophenyl)benzofuran-2-carboxylate (9). Yellowish-white powder, mp. 148$150{ }^{\circ} \mathrm{C}$; IR $\left(v_{\max }, \mathrm{cm}^{-1}\right): 3055,2930,1725,1561,1447,1306,1164 ;{ }^{1} \mathrm{H}$ NMR $\left(\mathrm{CDCl}_{3}\right): \delta_{\mathrm{H}} 4.01$ $\left(3 \mathrm{H}, \mathrm{s}, \mathrm{CO}_{2} \mathrm{CH}_{3}\right), 7.41-7.58\left(6 \mathrm{H}_{\text {arom }}, \mathrm{m}, 6 \mathrm{CH}\right), 7.65\left(1 \mathrm{H}_{\text {arom }}, \mathrm{s}, 1 \mathrm{CH}\right), 7.83\left(1 \mathrm{H}_{\text {arom }}, \mathrm{s}, 1 \mathrm{CH}\right) ;{ }^{13} \mathrm{C}$ NMR $\left(\mathrm{CDCl}_{3}\right): \delta_{\mathrm{C}} 52.4,112.6,113.9,120.9,125.8,127.1,127.5,128.6,133.4,136.3,139.3$,

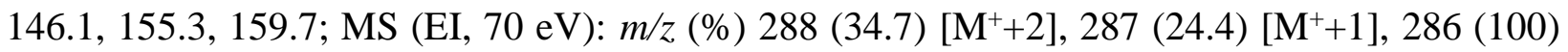
$\left[\mathrm{M}^{+}\right], 255$ (59.2), 199 (34.6), 163 (20.9), 127 (26.1), 100 (16.4), 81 (26.0). Anal. Calcd for $\mathrm{C}_{16} \mathrm{H}_{11} \mathrm{ClO}_{3}$ (286.71): C, 67.03; H, 3.87\%. Found: C, 67.31; H, 3.79\%.

Methyl 5-(4-methylphenyl)benzofuran-2-carboxylate (10). Pale grey powder, mp. 138-140 ${ }^{\circ} \mathrm{C}$; IR $\left(v_{\max }, \mathrm{cm}^{-1}\right): 3030,2953,2923,2844,1722,1560,1445,1298,1161 ;{ }^{1} \mathrm{H}$ NMR $\left(\mathrm{CDCl}_{3}\right): \delta_{\mathrm{H}} 2.42\left(3 \mathrm{H}, \mathrm{s}, \mathrm{CH}_{3}\right), 4.0\left(3 \mathrm{H}, \mathrm{s}, \mathrm{CO}_{2} \mathrm{CH}_{3}\right), 7.28\left(2 \mathrm{H}_{\text {arom }}, \mathrm{d},{ }^{3} J_{\mathrm{HH}} 7.8 \mathrm{~Hz}, 2 \mathrm{CH}\right), 7.49-$ $7.67\left(5 \mathrm{H}_{\text {arom }}, \mathrm{m}, 5 \mathrm{CH}\right), 7.84\left(1 \mathrm{H}_{\text {arom }}, \mathrm{s}, 1 \mathrm{CH}\right) ;{ }^{13} \mathrm{C} \mathrm{NMR}\left(\mathrm{CDCl}_{3}\right): \delta_{\mathrm{C}} 21.0,52.3,112.4,114.1$, 120.7, 125.7, 127.2, 127.3, 129.5, 136.9, 137.5, 137.9, 145.9, 155.1, 159.9; MS (EI, $70 \mathrm{eV}): \mathrm{m} / \mathrm{z}$ (\%) $266(50)\left[\mathrm{M}^{+}\right], 149$ (35.3), 105 (29.4), 85 (47.1), 70 (50.0), 57 (100). Anal. Calcd for $\mathrm{C}_{17} \mathrm{H}_{14} \mathrm{O}_{3}$ (266.29): C, 76.68; H, 5.30\%. Found: C, 76.93; H, 5.41\%.

Methyl 5-(4-trifluoromethylphenyl)benzofuran-2-carboxylate (11). Pale grey powder, mp. 146-147 ${ }^{\circ} \mathrm{C}$; IR $\left(v_{\max }, \mathrm{cm}^{-1}\right): 3110,3095,2958,2843,1723,1564,1432,1295,1195 ;{ }^{1} \mathrm{H}$ NMR $\left(\mathrm{CDCl}_{3}\right): \delta_{\mathrm{H}} 3.99\left(3 \mathrm{H}, \mathrm{s}, \mathrm{CO}_{2} \mathrm{CH}_{3}\right), 7.56-7.71\left(7 \mathrm{H}_{\text {arom }}, \mathrm{m}, 7 \mathrm{CH}\right), 7.86\left(1 \mathrm{H}_{\text {arom }}, \mathrm{s}, 1 \mathrm{CH}\right) ;{ }^{13} \mathrm{C} \mathrm{NMR}$ $\left(\mathrm{CDCl}_{3}\right): \delta_{\mathrm{C}} 52.4,112.7,113.9,121.4,125.6,125.7,125.8,126.0,127.2,127.6,136.0,144.3$,

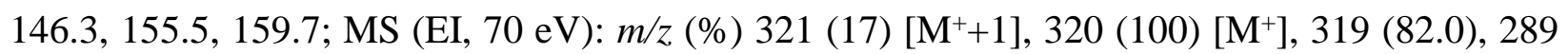
(84.3), 233 (55.0), 183 (15.0), 163 (21.2), 92 (11.2), 63 (23.8). Anal. Calcd for $\mathrm{C}_{17} \mathrm{H}_{11} \mathrm{~F}_{3} \mathrm{O}_{3}$ (320.26): C, 63.75; H, 3.46\%. Found: C, 63.88; H, 3.51\%.

Methyl 5-(4-methoxyphenyl)benzofuran-2-carboxylate (12). White powder, mp. 142-143 ${ }^{\circ} \mathrm{C}$; IR $\left(v_{\max }, \mathrm{cm}^{-1}\right): 3107,3033,2957,2928,2854,1722,1563,1445,1296,1163 ;{ }^{1} \mathrm{H}$ NMR $\left(\mathrm{CDCl}_{3}\right): \delta \mathrm{H} 3.86\left(3 \mathrm{H}, \mathrm{s}, \mathrm{OCH}_{3}\right), 3.99\left(3 \mathrm{H}, \mathrm{s}, \mathrm{CO}_{2} \mathrm{CH}_{3}\right), 7.00\left(2 \mathrm{H}_{\text {arom }}, \mathrm{d},{ }^{3} J_{\mathrm{HH}} 8.4 \mathrm{~Hz}, 2 \mathrm{CH}\right), 7.52-$ $7.63\left(5 \mathrm{H}_{\text {arom }}, \mathrm{m}, 5 \mathrm{CH}\right), 7.79\left(1 \mathrm{H}_{\text {arom }}, \mathrm{s}, 1 \mathrm{CH}\right) ;{ }^{13} \mathrm{C} \mathrm{NMR}\left(\mathrm{CDCl}_{3}\right): \delta_{\mathrm{C}} 52.3,55.3,112.3,114.1$, $114.3,120.5,125.7,125.8,127.2,127.4,128.4,133.4,137.2,154.9,159.1$; MS (EI, $70 \mathrm{eV}): \mathrm{m} / \mathrm{z}$ 
(\%) 282 (65.6) [M+], 281 (50.0), 266 (18.8), 167 (21.9), 149 (40.6), 83 (46.9), 70 (50.0), 57 (100). Anal. Calcd for $\mathrm{C}_{17} \mathrm{H}_{14} \mathrm{O}_{4}$ (282.29): C, 72.33; H, 5.00\%. Found: C, 72.16; H, 5.04\%.

Methyl 5-(3,4-methylenedioxyphenyl)benzofuran-2-carboxylate (13). Pale grey powder, mp. 119-121 ${ }^{\circ} \mathrm{C}$; IR ( $\left.v_{\max }, \mathrm{cm}^{-1}\right)$ : 3064, $3006,2953,2913,1725,1564,1500,1429,1311,1243,1229$; ${ }^{1} \mathrm{H}$ NMR $\left(\mathrm{CDCl}_{3}\right): \delta \mathrm{H} 3.91\left(3 \mathrm{H}, \mathrm{s}, \mathrm{CO}_{2} \mathrm{CH}_{3}\right), 5.93\left(2 \mathrm{H}, \mathrm{s}, \mathrm{OCH}_{2} \mathrm{O}\right), 6.80-6.99\left(3 \mathrm{H}_{\text {arom }}, \mathrm{m}, 3 \mathrm{CH}\right)$, 7.47-7.55 $\left(3 \mathrm{H}_{\text {arom }}, \mathrm{m}, 3 \mathrm{CH}\right), 7.69\left(1 \mathrm{H}_{\text {arom }}, \mathrm{s}, 1 \mathrm{CH}\right) ;{ }^{13} \mathrm{C} \mathrm{NMR}\left(\mathrm{CDCl}_{3}\right): \delta_{\mathrm{C}} 52.4,101.2,107.9$, 108.6, 112.4, 114.1, 120.7, 120.9, 127.3, 127.4, 135.2, 137.3, 145.9, 147.1, 148.1, 155.0, 159.9;

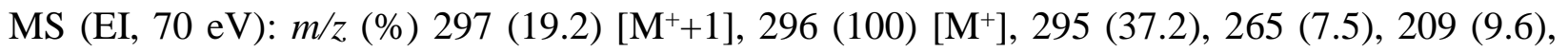
179 (12.8), 150 (14.9), 132 (29.1), 75 (17.8). Anal. Calcd for $\mathrm{C}_{17} \mathrm{H}_{12} \mathrm{O}_{5}$ (296.27): C, 68.92; H, $4.08 \%$. Found: C, 69.16; H, $4.21 \%$.

Methyl 5-(3-thienyl)benzofuran-2-carboxylate (14). Pale grey powder, mp. 117-118 ${ }^{\circ} \mathrm{C}$; IR $\left(v_{\max }, \mathrm{cm}^{-1}\right): 3111,3018,2958,1723,1567,1432,1295 ;{ }^{1} \mathrm{H} \mathrm{NMR}\left(\mathrm{CDCl}_{3}\right): \delta_{\mathrm{H}} 3.98(3 \mathrm{H}, \mathrm{s}$, $\left.\mathrm{CO}_{2} \mathrm{CH}_{3}\right), 7.38-7.71\left(5 \mathrm{H}_{\text {arom }}, \mathrm{m}, 5 \mathrm{CH}\right), 7.81\left(1 \mathrm{H}_{\text {arom }}, \mathrm{s}, 1 \mathrm{CH}\right), 7.85\left(1 \mathrm{H}_{\text {arom }}, \mathrm{s}, 1 \mathrm{CH}\right) ;{ }^{13} \mathrm{C} \mathrm{NMR}$ $\left(\mathrm{CDCl}_{3}\right): \delta_{\mathrm{C}} 52.4,112.5,113.8,114.0,120.3,125.4,125.8,126.5,127.4,130.7,141.9,146.5$, 155.1 159.8; MS (EI, $70 \mathrm{eV}): \mathrm{m} / z$ (\%) 258 (34.5) $\left[\mathrm{M}^{+}\right], 223$ (100), 198 (14.6), 167 (38.6), 149 (16.4), 119 (17.5), 88 (79.5), 62 (90.1). Anal. Calcd for $\mathrm{C}_{14} \mathrm{H}_{10} \mathrm{O}_{3} \mathrm{~S}$ (258.29): C, 65.10; H, 3.90; S, $12.41 \%$. Found: C, 65.35; H, 3.99; S, $12.46 \%$.

Suzuki coupling of ethyl 5-bromobenzofuran-2-carboxylate 15 with arylboronic acids 5a,b in toluene under microwave. A mixture of the ethyl 5-bromobenzofuran-2-carboxylate 15 (269 $\mathrm{mg}, 1 \mathrm{mmol})$, and the appropriate arylboronic acids $\mathbf{5 a , b}(1.2 \mathrm{mmol}), \mathrm{Pd}(\mathrm{II})$-complex 3 (0.4 $\mathrm{mg}$, $0.1 \mathrm{~mol} \%), \mathrm{Cs}_{2} \mathrm{CO}_{3}(651 \mathrm{mg}, 2 \mathrm{mmol})$ in toluene $(3 \mathrm{~mL})$ were mixed in a process vial. The vial was capped properly, and thereafter the mixture was heated under microwave irradiating conditions at $150{ }^{\circ} \mathrm{C}$ (200 Watt) for $23 \mathrm{~min}$ as shown in Scheme 2. After the reaction was almost complete (monitored by TLC), the reaction mixture was extracted with EtOAc ( 3 x $20 \mathrm{~mL})$. The combined organic extracts were dried over anhydrous $\mathrm{MgSO}_{4}$ then filtered off and the solvent was evaporated under reduced pressure. The products were purified with flash column chromatography using $n$-hexane/EtOAc (7:1) as an eluent to give the corresponding pure ethyl 5arylbenzofuran-2-carboxylates $\mathbf{1 6}$ and $\mathbf{1 7}$.

Ethyl 5-phenylbenzofuran-2-carboxylate (16). White powder, mp $110-11{ }^{\circ} \mathrm{C}$; IR ( $v_{\max }, \mathrm{cm}^{-}$ $\left.{ }^{1}\right): 3035,2951,2848,1731,1565,1444,1165 ;{ }^{1} \mathrm{H} \mathrm{NMR}\left(\mathrm{CDCl}_{3}\right): \delta_{\mathrm{H}} 1.46\left(3 \mathrm{H}, \mathrm{t},{ }^{3} J_{\mathrm{HH}} 7.2 \mathrm{~Hz}\right.$, $\left.\mathrm{CH}_{2} \mathrm{CH}_{3}\right), 4.48\left(2 \mathrm{H}, \mathrm{q},{ }^{3} \mathrm{~J}_{\mathrm{HH}} 7.2 \mathrm{~Hz}, \mathrm{CH}_{2} \mathrm{CH}_{3}\right), 7.38-7.68\left(8 \mathrm{H}_{\text {arom }}, \mathrm{m}, 8 \mathrm{CH}\right), 7.86\left(1 \mathrm{H}_{\text {arom, }}\right.$, $1 \mathrm{CH}) ;{ }^{13} \mathrm{C} \mathrm{NMR}\left(\mathrm{CDCl}_{3}\right): \delta_{\mathrm{C}} 14.3,61.5,112.4,113.8,120.9,125.7,127.2,127.4,127.6,128.1$, 128.8, 137.5, 140.9, 146.4, 155.2, 159.4; MS (EI, $70 \mathrm{eV}): m / z(\%) 267$ (19.9) $\left[\mathrm{M}^{+}+1\right], 266$ (100) $\left[\mathrm{M}^{+}\right], 238$ (59.1), 221 (33.6), 194 (22.7), 165 (54.9), 139 (10.8), 115 (12.5), 82 (25.1), 70 (12.7). Anal. Calcd for $\mathrm{C}_{17} \mathrm{H}_{14} \mathrm{O}_{3}$ (266.29): C, 76.68; H, 5.30. Found: C, 76.89; H, 5.44.

Ethyl 5-(4-chlorophenyl)benzofuran-2-carboxylate (17). Yellowish-white powder, mp 122$124{ }^{\circ} \mathrm{C}$; IR ( $\left.v_{\max }, \mathrm{cm}^{-1}\right): 3057,2924,2859,1733,1563,1454,1305,1167 ;{ }^{1} \mathrm{H} \mathrm{NMR}\left(\mathrm{CDCl}_{3}\right): \delta_{\mathrm{H}}$ $1.45\left(3 \mathrm{H}, \mathrm{t},{ }^{3} J_{\mathrm{HH}} 7.2 \mathrm{~Hz}, \mathrm{CH}_{2} \mathrm{CH}_{3}\right), 4.47\left(2 \mathrm{H}, \mathrm{q},{ }^{3} J_{\mathrm{HH}} 7.2 \mathrm{~Hz}, \mathrm{CH}_{2} \mathrm{CH}_{3}\right), 7.43\left(2 \mathrm{H}_{\text {arom }}, \mathrm{d},{ }^{3} J_{\mathrm{HH}} 8.7\right.$ $\mathrm{Hz}, 2 \mathrm{CH}), 7.51-7.65\left(5 \mathrm{H}_{\text {arom }}, \mathrm{m}, 5 \mathrm{CH}\right), 7.82\left(1 \mathrm{H}_{\text {arom }}, \mathrm{s}, 1 \mathrm{CH}\right) ;{ }^{13} \mathrm{C} \mathrm{NMR}\left(\mathrm{CDCl}_{3}\right): \delta_{\mathrm{C}} 14.3,61.6$, 112.6, 113.7, 120.9, 125.8, 127.0, 127.5, 128.5, 133.4, 136.2, 139.3, 146.5, 155.3, 159.4; MS (EI, 


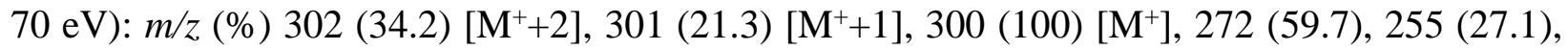
228 (15.8), 199 (28.1), 163 (28.1), 127 (20.3), 99 (16.0), 82 (32.9), 63 (19.0). Anal. Calcd for $\mathrm{C}_{17} \mathrm{H}_{13} \mathrm{ClO}_{3}$ (300.74): C, 67.89; H, 4.36\%. Found: C, 67.77; H, 3.43\%.

\section{Acknowledgements}

K.M.D is deeply indebted to Alexander von Humboldt foundation for granting him a CEM Discover LabmateTM microwave apparatus. El-Deftar thanks Cairo University for granting her the Graduate Research Challenge Fund.

\section{References}

1. Corbet, J. P.; Mignani, G. Chem. Rev. 2006, 106, 2651.

http://dx.doi.org/10.1021/cr0505268

PMid:16836296

2. Phan, N. T. S.; Van Der Sluys, M.; Jones, C. W. Adv. Synth. Catal. 2006, 348, 609. http://dx.doi.org/10.1002/adsc.200505473

3. Yin, L.; Liebscher, J. Chem. Rev. 2007, 107, 133.

http://dx.doi.org/10.1021/cr0505674

PMid:17212474

4. Alonso, F.; Beletskaya, I. P.; Yus, M. Tetrahedron 2008, 64, 3047.

http://dx.doi.org/10.1016/j.tet.2007.12.036

5. Capdeville, R.; Buchdunger, E.; Zimmermann, J.; Matter, A. Nat. Rev. Drug Discov. 2002, 1, 493.

http://dx.doi.org/10.1038/nrd839

PMid:12120256

6. McPhail, K. L.; Rivett, D. E. A.; Lack, D. E.; Davies-Coleman, M. T. Tetrahedron 2000, 56, 9391.

http://dx.doi.org/10.1016/S0040-4020(00)00910-8

7. Long, Y. Q.; Jiang, X. H.; Dayam, R.; Sachez, T.; Shoemaker, R.; Sei, S.; Neamati, N. J. Med. Chem. 2004, 47, 2561.

http://dx.doi.org/10.1021/jm030559k

PMid:15115398 
8. Moleele, S. S.; Michael, J. P.; de Koning, C. B. Tetrahedron Lett. 2006, 62, 2831. http://dx.doi.org/10.1016/j.tet.2006.01.013

9. Kertesz, M.; Choi, C. H.; Yang, S. Chem. Rev. 2005, 105, 3448. http://dx.doi.org/10.1021/cr990357p PMid:16218558

10. Kaye, S.; Fox, J. M.; Hicks, F. A.; Buchwald, S. L. Adv. Synth. Catal. 2001, 343, 789. http://dx.doi.org/10.1002/1615-4169(20011231)343:8<789::AID-ADSC789>3.0.CO;2-A

11. Kertesz, M.; Choi, C. H.; Yang, S. Chem. Rev. 2005, 105, 3448 http://dx.doi.org/10.1021/cr990357p PMid:16218558

12. Hall, D. G., In Boronic Acids Hall, D. G. Ed.; Wiley-VCH: Weinheim, Germany, 2005, pp 199.

13. Surendra, K.; Krishnaveni, N. S.; Sridhar, R.; Rao, K. R. J. Org. Chem. 2006, 71, 5819. http://dx.doi.org/10.1021/jo060805a PMid:16839175

14. Li, C. J. Chem. Rev. 2005, 105, 3095. http://dx.doi.org/10.1021/cr030009u PMid:16092827

15. Farina, V. Adv. Synth. Catal. 2004, 346, 1553. http://dx.doi.org/10.1002/adsc.200404178

16. Dupont, J.; Consorti, C. S.; Spencer, J. Chem. Rev. 2005, 105, 2527. http://dx.doi.org/10.1021/cr030681r PMid:15941221

17. Anderson, K. W.; Buchwald, S. L. Angew. Chem. Int. Ed. 2005, 44, 6173. http://dx.doi.org/10.1002/anie.200502017 PMid:16097019

18. Kappe, O.; Stadler, A. Microwaves in Organic and Medicinal Chemistry; WileyVCH:Weinhiem, 2005. 
19. Hoz, A.; Ortiz, A. D.; Moreno, A. Chem. Soc. Rev. 2005, 34, 164.

http://dx.doi.org/10.1039/b411438h

PMid:15672180

20. Kappe, C. O. Angew. Chem., Int. Ed. 2004, 43, 6250.

http://dx.doi.org/10.1002/anie.200400655

PMid:15558676

21. Larhed, M.; Moberg, C.; Hallberg, A. Acc. Chem. Res. 2002, 35, 717.

http://dx.doi.org/10.1021/ar010074v

PMid:12234201

22. Masubuchi, M.; Kawasaki, K.; Ebiike, H.; Ikeda, Y.; Tsujii, S.; Sogabe, S.; Fujii, T.; Sakata, K.; Shiratori, Y.; Aoki, Y.; Ohtsuka, T.; Shimma, N. Bioorg. Med. Chem. Lett. 2001, 11, 1833.

http://dx.doi.org/10.1016/S0960-894X(01)00319-5

23. Hayakawa, I.; Shioya, R.; Agatsuma, T.; Furukawa, H.; Naruto, S.; Sugano, Y. Bioorg. Med. Chem. Lett. 2004, 14, 455

http://dx.doi.org/10.1016/j.bmcl.2003.10.039

PMid:14698180

24. Li, W.; Hua, Y.; Li, J.; Thomason, J. R.; DeVincentis, D.; Du, X.; Wu, J.; Hotchandani, R.; Rush, T. S.; Skotnicki, J. S.; Tam, S.; Chockalingam, P. S.; Morris, E. A.; Levin, J. I. Bioorg. Med. Chem. Lett. 2009, 19, 4546

http://dx.doi.org/10.1016/j.bmcl.2009.07.008

PMid:19625186

25. Suh, J.; Yi, K. Y.; Lee, Y.-S.; Kim, E.; Yum, E. K.; Yoo, S.-E. Bioorg. Med. Chem. Lett. 2010, 20, 6362

http://dx.doi.org/10.1016/j.bmcl.2010.09.102

PMid:20943387

26. Dawood, K. M.; Kirschning, A. Tetrahedron 2005, 61, 12121.

http://dx.doi.org/10.1016/j.tet.2005.07.113

27. Solodenko, W.; Brochwitz, C.; Wartchow, R.; Hashem, Md. A.; Vaultier, M.; Dawood, K. M.; Kirschning, A. Mol. Div. 2005, 9, 333.

http://dx.doi.org/10.1007/s11030-005-7457-y

PMid:16311810 
28. Dawood, K. M.; Solodenko, W.; Kirschning, A. Arkivoc 2007 (v), 104.

29. Dawood, K. M. Tetrahedron 2007, 63, 9642. http://dx.doi.org/10.1016/j.tet.2007.07.029

30. Dawood, K. M.; Fayed, M. S.; Elkhalea, M. M. Arkivoc 2009, (xiii), 324.

31. Shaaban, M. R.; Darweesh, A. F.; Dawood, K. M.; Farag, A. F. Arkivoc 2010, (x), 208.

32. Darweesh, A. F.; Shaaban, M. R.; Farag, A. F.; Metz, P.; Dawood, K. M., Synthesis 2010, 3163.

33. Dawood, K. M.; El-Deftar, M. M. Arkivoc 2010, (ix), 319.

34. Dawood, K. M.; El-Deftar, M. M. Synthesis 2010, 1030. http://dx.doi.org/10.1055/s-0029-1218662

35. Abdel-Aziz, H. A.; El-Zahabi, H. S. A.; Dawood, K. M. Eur J. Med. Chem. 2010, 45, 2427. http://dx.doi.org/10.1016/j.ejmech.2010.02.026

PMid:20207452

36. Abdel-Aziz, H. A.; Mekawey, A. A. I.; Dawood, K. M. Eur J. Med. Chem. 2009, 44, 3637. http://dx.doi.org/10.1016/j.ejmech.2009.02.020

PMid:19321238

37. Dawood, K. M.; Abdel-Gawad, H.; Rageb, E. A.; Ellithey, M.; Mohamed, H. A. Bioorg. Med. Chem. 2006, 14, 3672.

http://dx.doi.org/10.1016/j.bmc.2006.01.033

PMid:16464601

38. Dawood, K. M.; Fuchigami, T. J. Org. Chem. 2004, 69, 5302.

http://dx.doi.org/10.1021/jo035871g

PMid:15287774

39. Goodwin, H. A.; Lions, F. J. Am. Chem. Soc. 1959, 81, 6415-6422. http://dx.doi.org/10.1021/ja01533a022

40. Torabi, A. A.; Souldozi, A.; Relter, R. Z. Kristallogr. - New Cryst. Struct. 2007, 222, 197. 
41. Vasilevsky, I. V.; Stenkamp, R. E.; Lingafelter, E. C.; Schomaker, V.; Willett, R. D.; Rose, N. J. Inorg. Chem. 1989, 28, 2619. http://dx.doi.org/10.1021/ic00312a023

42. Torabi, A. A.; Kian, R.; Souldozi, A.; Relter, R. Z. Kristallogr. - New Cryst. Struct. 2005, $220,613$.

43. Li, J.; Rush, T. S.; Li, W.; DeVincentis, D.; Du, X.; Hu, Y.; Thomason, J. R.; Xiang, J. S.; Skotnicki, J. S.; Tam, S.; Cunningham, K. M.; Chockalingham, P. S.; Morris, E. A.; Levin, J. I. Bioorg. Med. Chem. Lett. 2005, 15, 4961.

http://dx.doi.org/10.1016/j.bmcl.2005.08.001

PMid:16153831

44. Sall, D. J.; Arfsten, A. E.; Bastian, J. A.; Denney, M. L; Harms, C. S.; McCowan, J. R.; Morin, J. M.; Rose, J. W.; Scarborough, R. M.; Smyth, M. S.; Um, S. L.; Utterback, B. G.; Vasileff, R. T.; Wikel, J. H.; Wyss, V. L.; Jakubowski, J. A. J. Med. Chem. 1997, 40, 2843. http://dx.doi.org/10.1021/jm970020k

PMid:9288166

45. Yoo, S.-E.; Lee, S.-H.; Kim, S.-K.; Lee, S.-H. Bioorg. Med. Chem. 1997, 5, 445 http://dx.doi.org/10.1016/S0968-0896(96)00244-1

46. McPhillips, T. M.; McPhillips, S. E.; Chiu, H. J.; Cohen, A. E.; Deacon, A. M.; Ellis, P. J.; Garman, E.; Gonzalez, A.; Sauter, N. K.; Phizackerley, R. P.; Soltis, S. M.; Kuhn, P. J. Synchrotron Radiat. 2002, 9, 401. http://dx.doi.org/10.1107/S0909049502015170

47. Sheldrick, G. M. SHELX97, Programs for Crystal Structure Analysis; Universität Göttingen: Germany, 1998.

48. Barbour, L. J. J. Supramol. Chem. 2001, 1, 189. http://dx.doi.org/10.1016/S1472-7862(02)00030-8

49. Zhu, L.; Duquette, J.; Zhang, M. J. Org. Chem. 2003, 68, 3729. http://dx.doi.org/10.1021/jo0269114

PMid:12713390 